\title{
Ecology and diversity of a lizard community in the semiarid region of Brazil
}

\author{
Maria Jaqueline Monte de Andrade ${ }^{1,2,3}$, Raul Fernandes Dantas Sales ${ }^{I}$ \& Eliza Maria Xavier Freire ${ }^{I}$ \\ ${ }^{1}$ Laboratório de Herpetologia, Departamento de Botânica, Ecologia e Zoologia, \\ Centro de Biociências, Universidade Federal do Rio Grande do Norte-UFRN, \\ Campus Universitário Lagoa Nova, CEP 59072-970, Natal, RN, Brazil \\ ${ }^{2}$ Programa de Pós-Graduação em Ciências Biológicas, Centro de Biociências, \\ Universidade Federal do Rio Grande do Norte - UFRN, \\ Campus Universitário Lagoa Nova, CEP 59072-970, Natal, RN, Brazil \\ ${ }^{3}$ Corresponding author: Maria Jaqueline Monte de Andrade, e-mail: jackeline_monte@hotmail.com
}

ANDRADE, M.J.M., SALES, R.F.D. \& FREIRE, E.M.X. Ecology and diversity of a lizard community in the semiarid region of Brazil. Biota Neotrop. 13(3): http://www.biotaneotropica.org.br/v13n3/en/ abstract?article+bn04013032013

\begin{abstract}
Composition, species diversity and resource usage in terms of space and time were evaluated for the lizard community of the Ecological Station of the Seridó (ESEC Seridó), Rio Grande do Norte. An observation area of $150 \mathrm{~m} \times 150 \mathrm{~m}(2.25 \mathrm{ha})$ was delimited and surveyed monthly in alternate turns (morning, afternoon and night) for three consecutive days from April to October 2011, covering dry and rainy seasons. Fourteen species belonging to eight families were recorded, being Tropidurus semitaeniatus the most abundant. Seasonality influenced species richness and abundance. Regarding habitat usage, Lygodactylus klugei was the most generalist species, while Phyllopezus periosus, P. pollicaris and T. semitaeniatus were specialists, showing affinity for rocky formations. About microhabitat usage, the most generalist species was T. hispidus and the most specialized was L. klugei . Ten of the recorded species have diurnal habits and four are nocturnal. The space and time usage profiles of the dominant species corroborated data obtained in previous autoecological studies conducted in the same area and suggest a pattern of resource usage by these species in the ESEC Seridó.
\end{abstract}

Keywords: caatinga, activity periods, habitat use, microhabitat use, richness, seasonality.

ANDRADE, M.J.M., SALES, R.F.D. \& FREIRE, E.M.X. Ecologia e diversidade de uma comunidade de lagartos na região semiárida do Brasil. Biota Neotrop. 13(3): http://www.biotaneotropica.org.br/v13n3/pt/ abstract?article+bn04013032013

Resumo: Neste trabalho foram avaliadas a composição, diversidade de espécies e a utilização dos recursos espaço e tempo na comunidade de lagartos da Estação Ecológica do Seridó (ESEC Seridó), Rio Grande do Norte. Para isso, uma área de observação de $150 \mathrm{~m} \times 150 \mathrm{~m}$ (2,25 ha) foi delimitada e percorrida mensalmente em turnos alternados (manhã, tarde e noite) por três dias consecutivos nos meses de abril a outubro de 2011, cobrindo as estações seca e chuvosa. Foram registradas 14 espécies pertencentes a oito famílias, dentre as quais a mais abundante foi Tropidurus semitaeniatus. A sazonalidade influenciou a riqueza e abundância das espécies. Quanto ao uso do hábitat, Lygodactylus klugei foi a espécie mais generalista, enquanto Phylopezus periosus, P. pollicaris e T. semitaeniatus demonstraram especialidade às áreas de formações rochosas. Quanto ao uso de microhábitats, a espécie mais generalista foi T. hispidus e a mais especialista foi L. klugei. Dez das espécies registradas possuem hábito diurno e quatro são noturnas. Os perfis de uso do espaço e do tempo pelas espécies dominantes corroboram dados obtidos em estudos anteriores nesta mesma área e sugerem a existência de padrões na utilização desses recursos por estas espécies na ESEC Seridó.

Palavras-chave: caatinga, periodo de atividade, uso do habitat, uso do micro-habitat, riqueza, sazonalidade. 


\section{Introduction}

The Caatinga is a mosaic of thorny bushlands and seasonally dry forests occupying about $750.000 \mathrm{~km}^{2}$ of the Brazilian territory, bordered by the Atlantic Rainforest to the east, by the Amazonian Forest to the west and by the Cerrado to the south (Leal et al. 2005), being the only exclusively Brazilian biome (Silva et al. 2003, Leal et al. 2003, 2005). In spite of occupying a unique position among biomes, the Caatinga is the proportionally less studied one (Leal et al. 2003), a fact that maintained for a long time the idea of the Caatinga as being a homogeneous region, poor in biodiversity and endemisms. These assertions do not correspond with reality, because even being necessary more studies with wider geographical coverage, the Caatinga is more diverse than other regions with the same climate and soil conditions (Silva et al. 2003, Albuquerque et al. 2012).

Rodrigues (2003) recognized 47 lizard species for the Caatinga, apart from the species found in wet forest enclaves, which would make this biome as rich as the Cerrado and the Atlantic Rainforest (Rodrigues 2005). Despite this, the level of knowledge about the herpetofauna of the Caatinga is still considered unsatisfactory (Rodrigues 2003), because large areas of this biome were never sampled (Borges-Nojosa \& Arzabe 2005, Albuquerque et al. 2012) and many new species have been described in the last 15 years (e.g. Rodrigues 1996, Arias et al. 2011a, b).

In spite of lizards being considered model organisms for ecological studies, being easily handled animals and because they are more abundant and frequent to find than other reptiles (Rocha 1994), for a long time the only available paper about community ecology of lizards of the Caatinga was the result of a study developed in the Exu region, Pernambuco State (Vitt 1995). Ecological studies covering different geographical areas of the Caatinga are fundamental to test patterns, particularly those related to space usage, activity time, diet and reproduction. In this context, a long-term study, making part of the Long-Term Ecological Research Program (Programa de Pesquisas Ecológicas de Longa Duração) - PELD /CNPq Caatinga, was performed from 2002 to 2011 in a Conservation Unit of the Seridó region, Rio Grande do Norte State. The results of this study, partially summarized by Freire et al. (2009), were relevant to yield knowledge about lizard ecology in the Caatinga. Firstly, an inventory of the lizard species of the ESEC Seridó was conducted, including a survey on habitat usage and activity time of the dominant species (Kolodiuk 2005). At the same time, Maggi (2005) studied the population ecology of the geckos Phyllopezus periosus and $P$. pollicaris. Subsequently, substantial studies on behavioral ecology of the populations of Tropidurus hispidus and T. semitaeniatus (Ribeiro 2010, Ribeiro et al. 2008, 2010, 2012, Ribeiro \& Freire 2009a, b, 2010, 2011b, Kolodiuk et al. 2009, 2010) and of the populations of Ameiva ameiva and Ameivula cf. ocellifera (Sales et al. 2011a, b, 2012) were performed.

Considering nine study years since the initial inventory, and the results of the autoecological studies, this work had the objective of evaluating composition, diversity, space usage and activity periods of the lizard species in the ESEC Seridó, with the sight of consolidating the knowledge about community ecology of lizards in this Conservation Unit. This consolidation would be effective by answering the following questions: Is there a pattern, in terms of spatial distribution and habitat/microhabitat usage, for the species composing the lizard community of the ESEC Seridó? Could this pattern be confirmed for other similar areas of Caatinga (sensu stricto)? Does seasonality interfere with this pattern?

\section{Material and Methods}

\section{Study area}

This work was carried out in the ESEC Seridó (06 34' 36.2" S and $37^{\circ} 15^{\prime} 20.7^{\prime}$ ' W), a Conservation Unit occupying an area of 1,166.38 ha, in the municipality of Serra Negra do Norte, Seridó region, Rio Grande do Norte state (Varela-Freire 2002). Similar to other areas located in the Northern Depression (Depressão Sertaneja Setentrional), the ESEC Seridó supports climatic extremes, with low, open vegetation and extensive grasslands (Velloso et al. 2002). Irregularity in rainfall is one of the main factors of this ecorregion, characterized by hydric deficits along most of the year, reaching up to 10 dry months; the climate is semiarid, hot and dry (Bswh in Köppen's classification; Velloso et al. 2002). In general, the mean annual precipitation of the ESEC fluctuates between 500 and $800 \mathrm{~mm} /$ year (Varela-Freire 2002). In 2011, when this study was conducted, rainfall reached $1249 \mathrm{~mm}$ (Figure 1), being above the annual average for the area. Mean annual temperatures range between $28^{\circ} \mathrm{C}$ and $30{ }^{\circ} \mathrm{C}$, with highest temperatures reaching $40^{\circ} \mathrm{C}$ and lower ones between $17^{\circ} \mathrm{C}$ and $20^{\circ} \mathrm{C}$ (Varela-Freire 2002). Air relative humidity varies between 30 and $50 \%$ during dry season and between 80 and $90 \%$ in the rainy season (Varela-Freire 2002).

\section{Methodological procedures}

An inspection to choose a sampling area containing the different habitats covered by the ESEC was initially made. A $150 \mathrm{~m} \times 150 \mathrm{~m}$ square $(2.25 \mathrm{ha})$, close to the access pathway to the buffer zone of the ESEC $\left(06^{\circ} 34^{\prime} 72^{\prime}\right.$ ' S and $37^{\circ} 15^{\prime} 11^{\prime}$ ' W), was delimited in the selected area for observation and/or collecting of lizards. Fourteen transects, seven parallel and seven perpendiculars to the pathway, distant $25 \mathrm{~m}$ from each other were delineated. The crossings, every $25 \mathrm{~m}$, were marked with zebra tape as stop/sampling points for registering of lizards, making a total of 49 sample points (Figure 2).

Monthly visits from April to October of 2011 (except in August due to logistic reasons) were made. Three rainy months were considered along this period: April, May and June, being worth mentioning that despite June showed a low rainfall index (Figure 1), the vegetation was still exuberant as in the previous months, so June was considered a rainy season month. The three dry season months were July, September and October. The surveys were made by two collectors (MJMA and RFDS), with equal effort along the 14 transects and with intensive search at the stop points. The collectors traveled

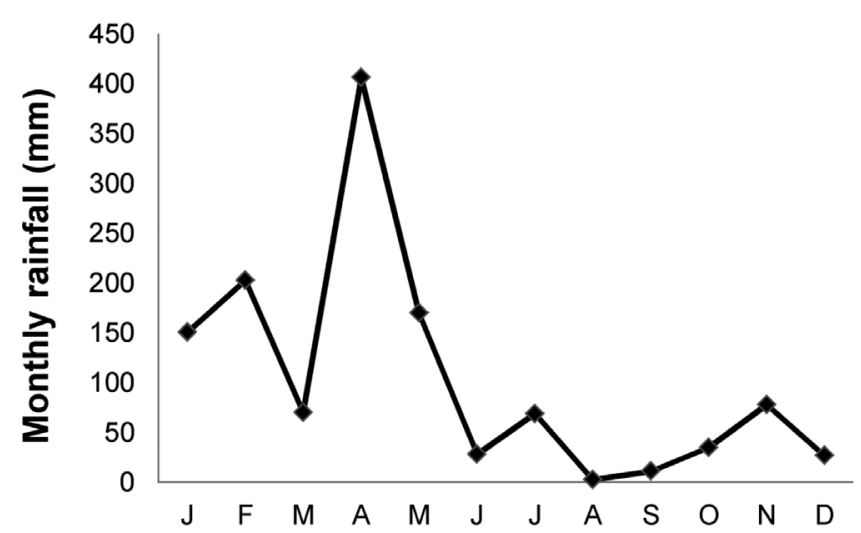

Figure 1. Total monthly rainfall recorded for the Ecological Station of the Seridó (ESEC Seridó) from January to October, 2011 (Source: Laboratório de Recursos Hídricos da Universidade Federal do Rio Grande do Norte). 


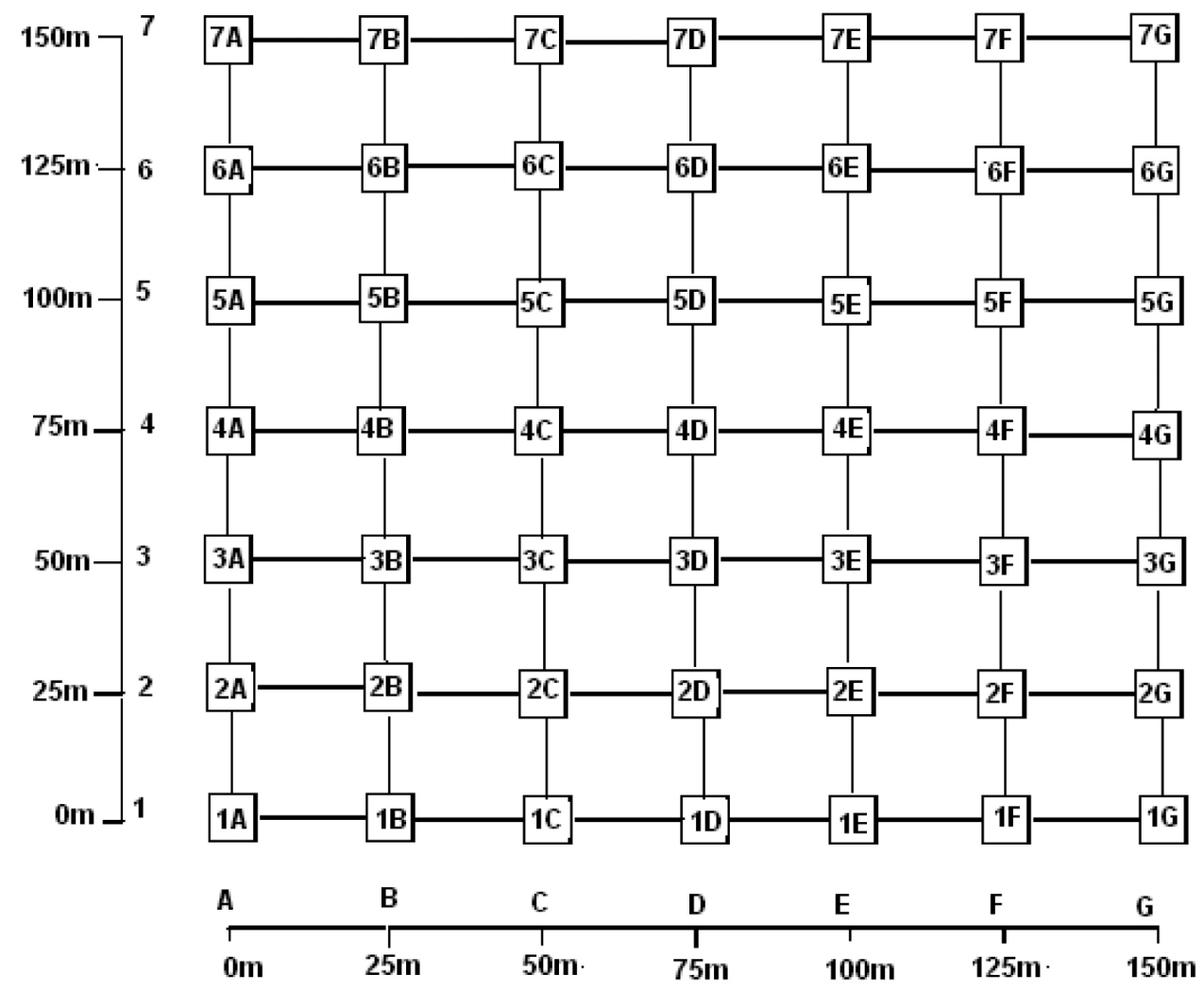

Figure 2. Sampling points marked in the $150 \mathrm{~m} \times 150 \mathrm{~m}$ (2.25 ha) quadrant delineated in the Ecological Station of the Serido (ESEC Seridó).

the transects during daytime and nighttime, in alternate turns, during 3 consecutive days each month. On the first day of each excursion, searches took place from $1800 \mathrm{~h}$ to $0000 \mathrm{~h}$, in the second from $0800 \mathrm{~h}$ to $1300 \mathrm{~h}$, and the third and final day from $0000 \mathrm{~h}$ to $0500 \mathrm{~h}$ and $1300 \mathrm{~h}$ to $1800 \mathrm{~h}$.

A detailed inspection of the environment was made at each stop point in a radius of $10 \mathrm{~m}$ around it, in order to characterize and identify the different physiognomies, and the predominant habitats along all the transects. Five different habitats were determined and categorized this way: Tree-Shrubby Vegetation (TSV), Dense Shrubby Vegetation (DSV), Sparse Shrubby Vegetation (SSV), Herbaceous Vegetation in Open Area (HVOA) and Areas with Rocky Formations (ARF). Ten microhabitat categories were identified and inspected in these five habitats, representing the place where the lizard specimens were firstly seen: Trees and Shrubs (TS); Soil with Herbaceous Vegetation (SHV), Soil with Leaf Litter (SLL), Exposed Soil (ES), Stony Soil (SS), On Decomposing Log or Branch (ODLB), Inside Decomposing Log or Branch (IDLB), On Boulder (OB), Rock Outcrop (RO), Crack of Rock Outcrop (CRO).

Each individual observed in the field was identified and notes with information about habitat and microhabitat, light exposition category for diurnal species (sunlight or shade), and date and time of observation were recorded. To measure activity periods of the species, observations of active individuals were categorized in one-hour intervals, ranging from 00 to 59 minutes (e.g. $1300 \mathrm{~h}$ to $1359 \mathrm{~h}$ ). A few specimens, unidentifiable in the field, were collected and examined in the laboratory, where they were identified, fixed in $10 \%$ formalin, preserved in $70 \%$ ethanol and deposited in the Herpetological Collection of the Universidade Federal do Rio Grande do Norte (CHBEZ).

\section{Quantitative data analysis}

The niche amplitude of each species for space and time dimensions was calculated by the inverse of Simpson's Diversity Index (Simpson 1949). It is worth to highlight that inactive individuals were not included in the analysis of niche amplitude for time, just for space usage. The difference in the values of niche amplitude in the species for the dry and the rainy season was calculated through a paired Student's t-test. Niche overlap was examined using the Pianka's Overlap Index - $\mathrm{O}_{\mathrm{jk}}$ (Pianka 1973). Both indexes were calculated in the Ecological Methodology program (Kenney \& Krebs 2000), and only species with $n \geq 5$ were considered in the analyses. Diversity in rainy and dry seasons was obtained using the ShannonWiener Index (H') (Magurran 1988).

\section{Results}

\section{Species richness and abundance}

Sampling effort totalized 95 hours (155 man-hours, 79 during daytime and 76 during nighttime; 75 during the rainy season and 80 during the dry season). A total of 663 records of habitat and microhabitat usage were made (643 for active individuals and 20 for inactive individuals). Fourteen species, belonging to eight families were recorded (Table 1). Most of the field records belonged to the following species in descending order: Tropidurus semitaeniatus (45.2\%), Phyllopezus periosus (15.5\%), T. hispidus (13.4\%), P. pollicaris $(9.2 \%)$, Ameivula cf. ocellifera $(6.8 \%)$, Ligodactylus klugei (4.2\%), Hemidactylus agrius (2.3\%) and Gymnodactylus geckoides (1.2\%) (Figure 3 and 4 ). 
Andrade, M.J.M. et al.

Table 1. Lizard species and number of visual records in the different habitats of the Ecological Station of the Seridó (ESEC Seridó), along the period of April to October 2011. ARF: Areas with Rocky Formations, DSV: Dense Shrubby Vegetation, SSV: Sparse Shrubby Vegetation, TSV: Tree-Shrubby Vegetation and HVOA: Herbaceous Vegetation in Open Area. A dash (-) indicates absence of records.

\begin{tabular}{|c|c|c|c|c|c|}
\hline & ARF & DSV & SSV & ASV & HVOA \\
\hline \multicolumn{6}{|l|}{ Gekkonidae } \\
\hline Hemidactylus agrius Vanzolini 1978 & 11 & 3 & - & 1 & - \\
\hline Lygodactylus klugei (Smith, Martin \& Swain, 1977) & 9 & 9 & 5 & 5 & - \\
\hline \multicolumn{6}{|l|}{ Gymnophtalmidae } \\
\hline Vanzosaura rubricauda (Boulenger 1902) & 1 & - & - & - & - \\
\hline \multicolumn{6}{|l|}{ Iguanidae } \\
\hline Iguana iguana (Linnaeus, 1758) & - & - & 1 & - & - \\
\hline \multicolumn{6}{|l|}{ Phyllodactylidae } \\
\hline Gymnodactylus geckoides Spix, 1825 & 2 & 1 & 3 & 2 & - \\
\hline Phyllopezus periosus Rodrigues, 1986 & 103 & - & - & - & - \\
\hline Phyllopezus pollicaris Spix, 1825 & 60 & - & 1 & - & - \\
\hline \multicolumn{6}{|l|}{ Polychrotidae } \\
\hline Polychrus acutirostris Spix, 1825 & - & - & - & 1 & - \\
\hline \multicolumn{6}{|l|}{ Scincidae } \\
\hline Mabuya heathi (Schimdt \& Inger, 1951) & - & 1 & 2 & 2 & - \\
\hline \multicolumn{6}{|l|}{ Teiidae } \\
\hline Ameiva ameiva (Linnaeus,1758) & 1 & - & - & 3 & - \\
\hline Ameivula cf. ocellifera (Spix, 1825) & 3 & 8 & 24 & 1 & 9 \\
\hline Salvator merianae (Duméril \& Bibron,1839) & 2 & - & - & - & - \\
\hline \multicolumn{6}{|l|}{ Tropiduridae } \\
\hline Tropidurus hispidus (Spix, 1825) & 43 & 25 & 9 & 12 & - \\
\hline Tropidurus semitaeniatus (Spix, 1825) & 256 & 23 & 14 & 7 & - \\
\hline Total & 491 & 70 & 59 & 34 & 9 \\
\hline
\end{tabular}

Of 14 recorded species, eight were seen during both seasons, four only during the rainy season and just two exclusively during the dry season (Iguana iguana and Polychrus acutirostris) (Figure 3). The five most frequent species showed a higher abundance during the rainy season (Figure 4). Most individuals of the geckos L. klugei, H. agrius, and G. geckoides were recorded in the dry season (Figure 4). Even the rainy season showing a higher richness and abundance of individuals, the total diversity was the same for both seasons $\left(\mathrm{H}^{\prime}=2.4\right)$.

\section{Habitat usage}

The most used habitat by the lizard species was Areas with Rocky Formations (ARF), showing the greatest richness and the highest number of recorded individuals (Table 1). In total, 11 of the 14 observed species and $74 \%(n=491)$ of the individual visual records made in this study happened in this habitat. On the other hand, the habitat of Herbaceous Vegetation in Open Area (HVOA) was the poorest, with just a single species, A. cf. ocellifera, and also the lowest number of individual visual records: $1.3 \%(\mathrm{n}=9)$ (Table 1).

The most generalist species in terms of habitat usage were L. klugei $\left(\mathrm{B}_{\mathrm{H}}=3.69\right)$, G. geckoides $\left(\mathrm{B}_{\mathrm{H}}=3.55\right)$ and T. hispidus $\left(\mathrm{B}_{\mathrm{H}}=2.93\right)$ (Table 2$)$. The species with more restricted exigencies/ fidelity in habitat usage, with $\mathrm{B}_{\mathrm{H}}=1$, was $P$. periosus, followed by $P$. pollicaris with $\mathrm{B}_{\mathrm{H}} 1.03$, and $T$. semitaeniatus with $\mathrm{B}_{\mathrm{H}}=1.35$ (Table 2 ). No significant difference was identified in the niche amplitude of the species between seasons $(\mathrm{t}=-1.401 ; \mathrm{gl}=7 ; \mathrm{p}=0.204)$.

Most of the species pairs showed high niche overlaps in habitat usage (Table 3). The highest overlapping was confirmed for $P$. periosus and $P$. pollicaris $\left(\varnothing_{\mathrm{Ppe} \times} \varnothing_{\mathrm{Ppo}}=0.999\right)$, followed by the overlaps between each of these two species and $T$. semitaeniatus (Table 3). Low overlapping indexes were obtained between $A$. cf. ocellifera and $H$. agrius, and between $A$. cf. ocellifera and the species using mainly ARF (P. periosus, $P$. pollicaris and T. semitaeniatus)
Table 2. Space niche amplitude for habitat $\left(\mathrm{B}_{\mathrm{H}}\right)$ and microhabitat $\left(\mathrm{B}_{\mathrm{M}}\right)$ of the species of lizards $(n \geq 5)$ in the ESEC Seridó, along the period of April to October, 2011.

\begin{tabular}{lccc}
\hline \multicolumn{1}{c}{ Species } & $\mathbf{n}$ & $\mathbf{B}_{\mathbf{H}}$ & $\mathbf{B}_{\mathbf{M}}$ \\
\hline T. semitaeniatus & 300 & 1.35 & 2.55 \\
P. periosus & 103 & 1 & 4.08 \\
T. hispidus & 89 & 2.93 & 5.37 \\
P. pollicaris & 61 & 1.03 & 4.08 \\
A. cf. ocellifera & 45 & 2.77 & 1.69 \\
L. klugei & 28 & 3.69 & 1.32 \\
H. agrius & 15 & 1.71 & 4.41 \\
G. geckoides & 8 & 3.55 & 1.6 \\
M. heathi & 5 & 2.77 & 1 \\
\hline
\end{tabular}

(Table 3). A markedly low overlapping index was also obtained between Mabuya heathi and the following species: P. pollicaris, $T$. semitaeniatus and H. agrius (Table 3). Overlapping was null just between $M$. heathi and P. periosus.

\section{Microhabitat usage}

The highest numbers of species records happened in the microhabitats Soil with Herbaceous Vegetation (SHV), On Decomposing Log or Branch (ODLB) and Trees and Shrubs (TS), with the respective occurrence of seven, six and six species. The microhabitats Exposed Soil (ES), Stony Soil (SS) and Inside Decomposing Log or Branch (IDLB) were the poorest, with just three species found at each one. The microhabitat ES was used by $T$. semitaeniatus, T. hispidus and Salvator merianae; SS was used by T. semitaeniatus, A. ameiva and Vanzosaura rubricauda, and IDLB 


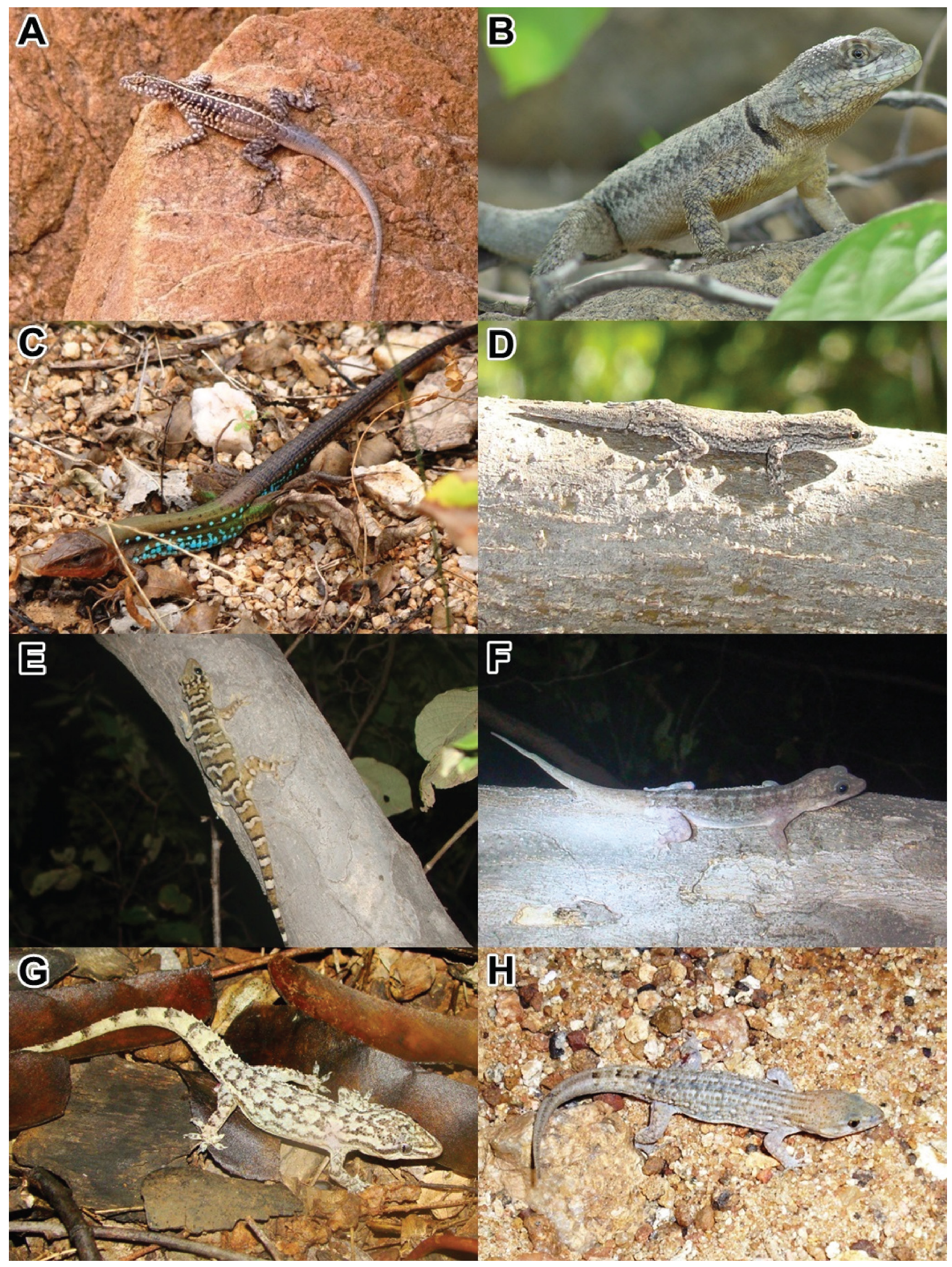

Figure 3. The eight most abundant lizard species in the Ecological Station of the Seridó (ESEC Seridó) in this study, along the period of April to October 2011. (A) Tropidurus semitaeniatus, (B) T. hispidus, (C) Ameivula cf. ocellifera, (D) Ligodactylus klugei, (E) Phyllopezus periosus, (F) P. pollicaris, (G) Hemidactylus agrius, (H) Gymnodactylus geckoides. 
Andrade, M.J.M. et al.

Table 3. Overlapping values for spatial niche. Values above the traced diagonal correspond to habitat usage and values below the diagonal correspond to microhabitat usage, obtained for the lizard species $(\mathrm{n} \geq 5)$ of the Ecological Station of the Seridó (ESEC Seridó), along the period of April to October 2011. For both categories analyzed, the boldface values correspond to the highest overlapping indexes, while those in italics correspond to the lowest indexes. Acronyms represent the initials of the specific names, according to Table 1.

\begin{tabular}{cccccccccc}
\hline & T.sem & P.per & T.his & P.pol & A. oce & L. klu & H. agr & G. gec & M. hea \\
\hline T.sem & - & $\mathbf{0 . 9 9 4}$ & 0.881 & $\mathbf{0 . 9 9 4}$ & 0.186 & 0.697 & $\mathbf{0 . 9 8 1}$ & 0.54 & 0.08 \\
P.per & $\mathbf{0 . 7 5 0}$ & - & 0.827 & $\mathbf{0 . 9 9 9}$ & 0.11 & 0.618 & $\mathbf{0 . 9 6 1}$ & 0.471 \\
T.his & $\mathbf{0 . 7 1 2}$ & 0.639 & - & 0.83 & 0.396 & $\mathbf{0 . 9 4 7}$ & $\mathbf{0 . 9 4 1}$ & 0.734 \\
P.pol & $\mathbf{0 . 7 8 7}$ & $\mathbf{0 . 8 7 3}$ & $\mathbf{0 . 7 3 5}$ & - & 0.125 & 0.623 & $\mathbf{0 . 9 6}$ & 0.483 & 0.429 \\
A. oce & 0.019 & 0 & 0.209 & 0 & - & 0.569 & 0.187 & 0.767 & 0.715 \\
L. klu & 0.072 & 0.548 & 0.329 & 0.461 & 0 & - & 0.786 & 0.841 & 0.663 \\
H. agr & 0.378 & 0.274 & $\mathbf{0 . 7 4 4}$ & 0.468 & 0.158 & 0.092 & - & 0.556 & 0.145 \\
G. gec & 0.008 & 0 & 0.115 & 0.03 & 0.11 & 0 & 0.664 & - & 0.864 \\
M. hea & 0.01 & 0 & 0.07 & 0 & $\mathbf{0 . 9 2 6}$ & 0 & 0 & 0 \\
\hline
\end{tabular}

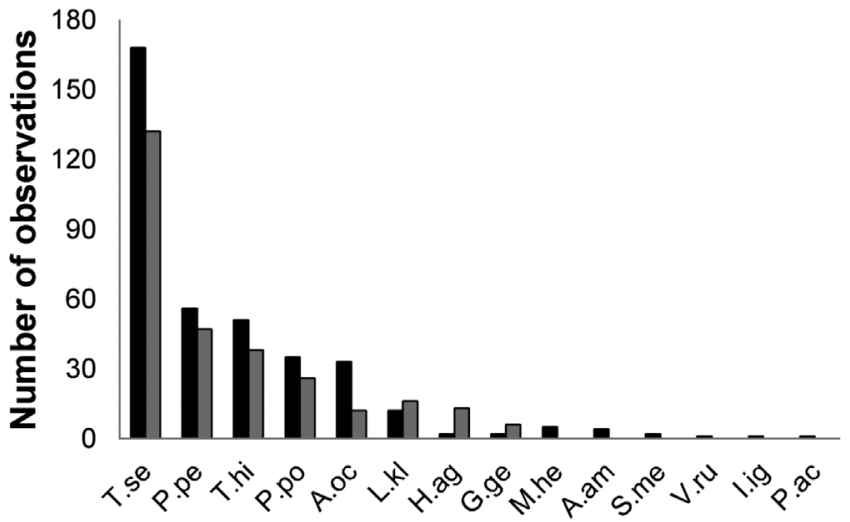

Figure 4. Absolute abundance of visual records of lizard species of the Ecological Station of the Seridó (ESEC Seridó), during the dry (grey bars) and rainy (black bars) seasons, along the period of April to October 2011. Acronyms represent the initials of the specific names, according to Table 1.

by G. geckoides, H. agrius and P. pollicaris. Rock Outcrop (RO) microhabitat was the one with the highest percentage of individuals $(33.4 \%, n=222)$, while Exposed Soil (ES) yielded the lowest number of records, just $0.7 \%(n=5)$.

The most generalist species in terms of microhabitat usage were T. hispidus $\left(\mathrm{B}_{\mathrm{M}}=5.37\right)$, H. agrius $\left(\mathrm{B}_{\mathrm{M}=} 4.41\right)$, P. periosus $\left(\mathrm{B}_{\mathrm{M}}=4.08\right)$ and $P$. pollicaris $\left(\mathrm{B}_{\mathrm{M}}=4.08\right)$ (Table 2$)$. The most microhabitat usage-restricted species was $M$. heathi $\left(\mathrm{B}_{\mathrm{M}}=1\right)$, which occurred just in Soil with Herbaceous Vegetation (SHV), followed by L. klugei $\left(\mathrm{B}_{\mathrm{M}}=1.32\right)$, which used mainly Trees and Shrubs (TS), and by $A$. cf. ocellifera $\left(\mathrm{B}_{\mathrm{M}}=1.69\right)$ (Table 2$)$, with most of its records happening in SHV. No significant difference was identified in the niche amplitude of the species between seasons $(\mathrm{t}=0.569 ; \mathrm{gl}=7 ; \mathrm{p}=0.587)$.

An almost complete overlapping in microhabitat usage $(\varnothing=0.926)$ happened only between the pair of species using mostly SHV: A. cf. ocellifera and $M$. heathi $\left(\varnothing_{\text {Ao x Mh }}=0.926\right)$, followed by the overlapping among the dominant species using mostly ARF (P. pollicaris X P. periosus X T. semitaeniatus) (Table 3 ) and the two more generalist species in terms of microhabitat usage: $H$. agrius and T. hispidus $\left(\varnothing_{\text {Ha х Th }}=0.744\right)$. In most of the cases, overlapping was null or very low (Table 3 ).

\section{Activity periods}

Ten of the fourteen species composing this lizard assemblage have diurnal habits, with an activity period between $0800 \mathrm{~h}$ and $1700 \mathrm{~h}$ (Figure 5). The nocturnal species (P. pollicaris, P. periosus, H. agrius and $G$. geckoides) showed an activity period between $1800 \mathrm{~h}$ and $0500 \mathrm{~h}$ (Figure 5); G. geckoides and P. periosus were also registered during the day, with G. geckoides being hidden, while P. periosus was active (see below).

Among the diurnal species, L. klugei $\left(\mathrm{B}_{\mathrm{T}}=8.57\right)$, T. hispidus $\left(\mathrm{B}_{\mathrm{T}}=8.51\right)$ and T. semitaeniatus $\left(\mathrm{B}_{\mathrm{T}}=8.31\right)$ were the species with a wider niche amplitude and showed wider and/or bimodal activity profiles (Figure 5A, B and D). These three species share the specificities of being recorded from the initial hours of observation, remaining active all day long, but with reduction of activity during the hottest hours. However, during the rainy season, L. klugei started activities later, around $1000 \mathrm{~h}$, without any reduction of activity until the end of the day (Figure 5D). A relatively narrower niche amplitude value $\left(\mathrm{B}_{\mathrm{T}}=4.60\right)$, when compared with the tropidurids, was obtained for the teiid $A$. cf. ocellifera, reflecting and intermediate activity period (Figure 4C); this species started activities around 0800 $\mathrm{h}$, reaching the highest number of appearances in the hottest hours and ending activities early, around $1400 \mathrm{~h}$ (Figure 5C). On the other hand, $M$. heathi presented the narrowest niche amplitude $\left(\mathrm{B}_{\mathrm{T}}=1.8\right)$ and showed a bimodal profile, during the initial and final hours of the day, corresponding to moderate temperatures (Figure 5E).

Among the nocturnal species, $P$. periosus $\left(\mathrm{B}_{\mathrm{T}}=9.51\right)$ and $P$. pollicaris $\left(\mathrm{B}_{\mathrm{T}}=7.68\right)$ were the ones with a wider activity period (Figure $5 \mathrm{~F}$ and $\mathrm{G}$ ). These species remained active during all the nocturnal observation period in both seasons. Furthermore, P. periosus was active not only at night; two individual were found active at the end of the afternoon, between $1700 \mathrm{~h}$ and $1800 \mathrm{~h}$ (Figure 5G), and one individual was found active at $0900 \mathrm{~h}$ (not shown in Figure 4). An intermediate value for niche amplitude $\left(\mathrm{B}_{\mathrm{T}}=5.26\right)$ was obtained for $H$. agrius, with a very variable activity along the night and being recorded mainly during the dry season (Figure $4 \mathrm{H}$ ). No significant difference was identified in the niche amplitude of the species between seasons $(\mathrm{t}=0.652 ; \mathrm{gl}=6 ; \mathrm{p}=0.539)$.

The greatest overlapping in temporal niche happened between T. hispidus and T. semitaeniatus $\left(\varnothing_{\mathrm{Th} \times \mathrm{Ts}}=0.938\right)$, followed by P. periosus and P. pollicaris $\left(\varnothing_{\mathrm{Ppe} \times \mathrm{Ppo}}=0.891\right)$, and by L. klugei and the tropidurids $\left(\varnothing_{\mathrm{LkxTs}}=0.898\right.$ and $\left.\varnothing_{\mathrm{LkxT}} \mathrm{h}=0.795\right)$. Null or markedly low overlapping indexes were obtained mostly between nocturnal and diurnal species.

\section{Considerations about seasonal variation for sunny and/ or shaded microhabitat usage}

Variations in the usage profiles of sunny and shaded microhabitats were recorded for the most common diurnal species $(n \geq 10)$. During the rainy season, tropidurids made use of sunny microhabitats along 

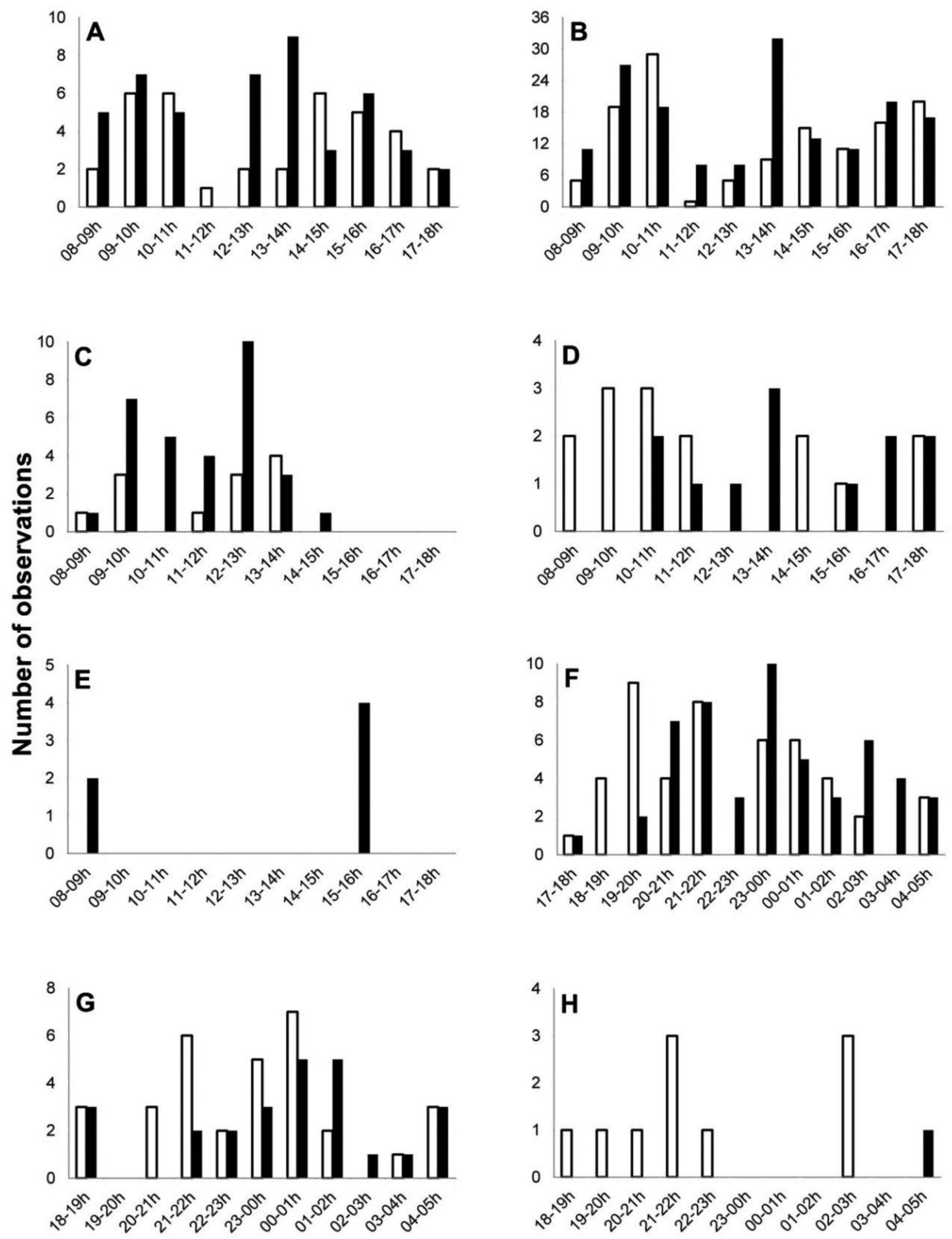

Figure 5. Activity periods of lizard species $(\mathrm{n} \geq 5)$ of the Ecological Station of the Seridó (ESEC Seridó), during the dry season (white bars) and rainy season (back bars), along the period of April to October 2011. Diurnal species: (A) Tropidurus semitaeniatus, (B) T. hispidus, (C) Ameivula cf. ocellifera, (D) Ligodactylus klugei, (E) Mabuya heathi. Nocturnal species: (F) Phyllopezus periosus, (G) P. pollicaris, (H) Hemidactylus agrius. 

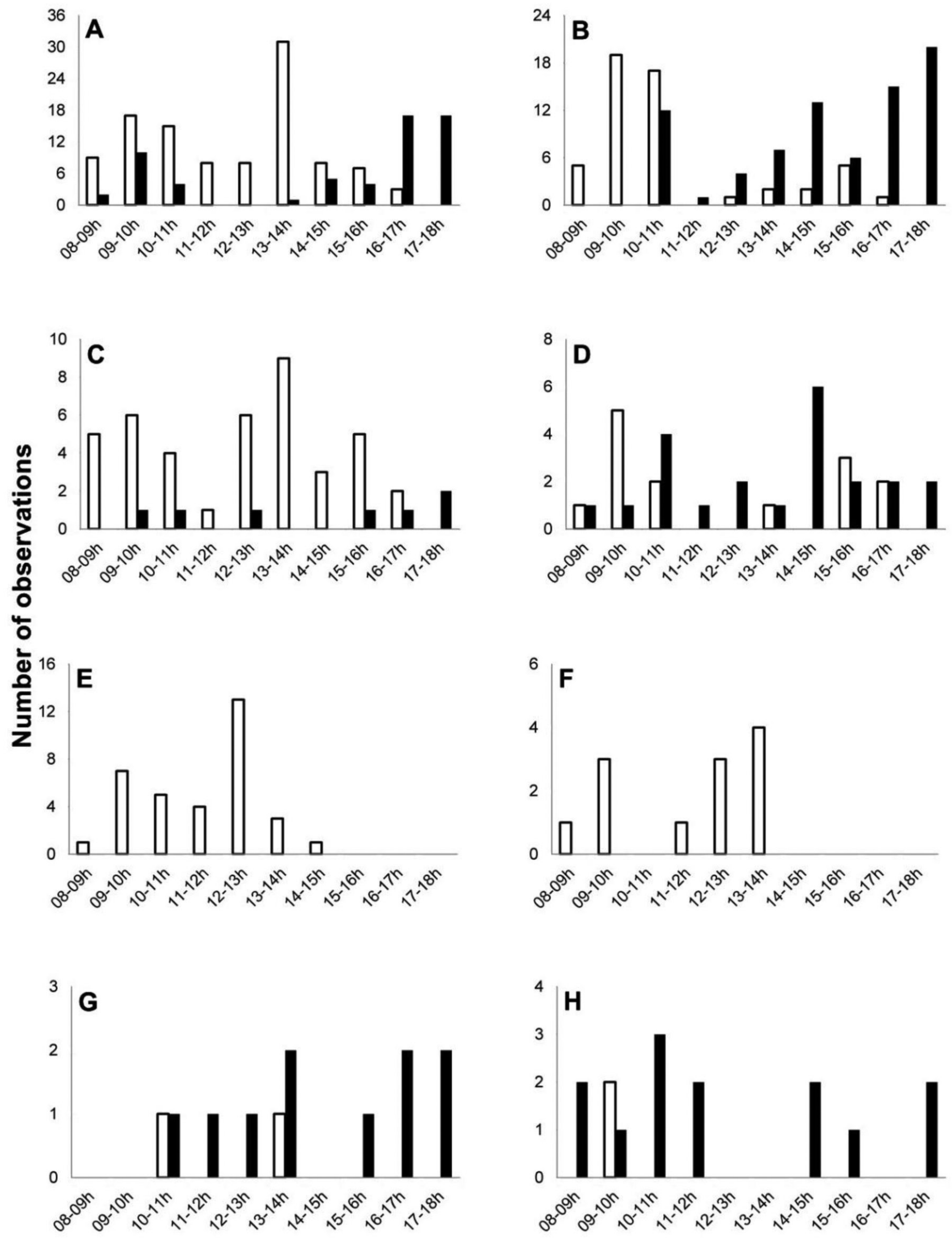

Figure 6. Usage of sunny (white bars) and shaded (black bars) microhabitats by Tropidurus semitaeniatus (A, B), T. hispidus (C, D), Ameivula cf. ocellifera $(\mathrm{E}, \mathrm{F})$ and Ligodactylus klugei $(\mathrm{G}, \mathrm{H})$ in the Ecological Station of the Seridó (ESEC Seridó), during the dry (A, C, E, G) and rainy (B, D, F, H) seasons. 
all of the day (Figure 6A and C), while in the dry season they used mainly shaded microhabitats (Figure 6B and D). On the other hand, the profiles of light exposition of A. cf. ocellifera and L. klugei were similar along seasons; $A$. cf. ocellifera used just sunny microhabitats (Figure 6E and F), while L. klugei was recorded mainly from shaded environments (Figure 6G and $\mathrm{H}$ ).

\section{Discussion}

Of the 16 species recorded by Freire et al. (2009) for the ESEC Seridó, just two (Hemidactylus brasilianus e Micrablepharus maximiliani) were not found during this study performed in the same area. The longer sampling effort during the first work (several field excursions between 2002 and 2008) could have been a factor responsible for this difference. The richness of the lizard community of the ESEC Serido is, therefore, similar to that found in other areas of Caatinga sensu stricto (Andrade-Lima 1981), considering that the richness of these areas oscillates between 10 and 19 species, depending on the locality (Vanzolini et al. 1980, Vitt 1995, Ribeiro \& Freire 2011a, Moura et al. 2010, Garda et al. 2013).

The most frequent species in this study was T. semitaeniatus, which is a typical species of the Caatinga biome (Vitt 1995, Rodrigues 2003, Freire et al. 2009), but has also been registered in a transitional area between Caatinga and "campos rupestres" (rocky fields) (Menezes et al. 2011) and in the Atlantic Rainforest biome (Freire 2001). The second and third most abundant diurnal species (T. hispidus and A. cf. ocellifera) are common in the open formations of Brazil (Vitt 1995, Rodrigues 2003). Ameivula cf. ocellifera is a new species widely distributed in the Caatinga (F. Arias, pers. comm.), formerly treated as A. ocellifera in several studies (e.g. Vitt 1995, Ribeiro et al. 2011, Sales et al. 2012). These results agree with the data obtained by Kolodiuk (2005) for the ESEC Seridó, except for $A$. cf. ocellifera being more abundant than T. hispidus in that study, a fact that might have been the result of a more extensive sampling in the habitat of Herbaceous Vegetation in Open Area (HVOA). New information arising from this study is the presence of L. klugei among the most frequent species, confirming its predominance in open formations (Vitt 1995, Rodrigues 2003, Werneck et al. 2009).

The most frequent nocturnal species was $P$. periosus, endemic to the Caatinga and widely distributed across this biome at the present time, being found in the states of Alagoas, Pernambuco, Paraiba and Rio Grande do Norte (Freire et al. 2000, 2009). The second most frequent nocturnal species was $P$. pollicaris, a widespread species in the Caatinga (Vitt 1995, Rodrigues 1986, 2003). These results contradicts those obtained by Maggi (2005), who indicated that $P$. pollicaris was much more abundant than $P$. periosus. It is probable that this difference could be related with differences in the physiognomy of the sampled areas.

The relatively common occurrence of $H$. agrius is a quite relevant novelty, as it was a rare species in other areas of the Caatinga (Vanzolini et al. 1980, Vitt 1995) and relictual in distribution (Rodrigues 2003). On the other hand, H. mabouia, which is a widespread invasive species in urban areas as well as in natural environments belonging to several different biomes, including the Caatinga (Vanzolini et al. 1980, Vitt 1986, 1995, Rodrigues 2003, Rocha et al. 2011), remains unrecorded from the ESEC Seridó (Freire et al. 2009 and this study), a fact worth to be further investigated.

Seasonality represented an important influence on the lizard assemblage of the ESEC, as most of the species showed a higher number of records during the rainy season and a decrease in the dry season, thus confirming the results obtained by Kolodiuk et al. (2010), Ribeiro (2010) and Sales et al. (2011a). These authors suggested that this variation may be related to more pleasant temperatures and/or more food availability during the rainy season.

As for habitat usage, the highest richness and frequency of species in the Areas with Rocky Formations (ARF) may be related to the great abundance of this kind of areas in the ESEC Seridó (Freire et al. 2009, Ribeiro \& Freire 2010), while the wide variety of available microhabitats, such as leaf litter and rock crevices, propitiate, mainly during the dry season, microhabitats with more pleasant temperatures (Mares et al. 1981).

Habitat usage by the most common species agrees with profiles already described for the ESEC Seridó by Kolodiuk (2005), Maggi (2005), Freire et al. (2009), Kolodiuk et al. (2009, 2010) and Ribeiro (2010), as these studies also showed T. hispidus as the most generalist species (Kolodiuk 2005, Ribeiro 2010) and A. cf. ocellifera occurring mostly in the Herbaceous Vegetation in Open Area (HVOA) (Kolodiuk 2005). The low values for niche amplitude recorded for T. semitaeniatus, $P$. periosus and P. pollicaris indicate specialization for the habitat of Areas with Rocky Formations (ARF). Other species lacking autoecological studies in the ESEC Seridó, such as L. klugei and $M$. heathi, showed high values of niche amplitude and, therefore, make part of the group of generalist species in terms of habitat usage, differing from the results achieved by Vitt (1995).

In spite of a considerable segregation between some pairs of species regarding habitat usage, there was high overlapping among the majority of the species of this assemblage. However, it is possible that divergences in other niche variables may exist, as sympatric species use to be segregated in at least one niche dimension like microhabitat, activity time and diet, or combinations of those variables (Vitt 1995, Werneck et al. 2009).

About microhabitat usage, this study showed that $T$. semitaeniatus was a strictly saxicolous species, $T$. hispidus was present in most of the microhabitats, and $A$. cf. ocellifera showed terrestrial habits, thus agreeing with the profiles outlined in previous studies performed in the ESEC Seridó (Kolodiuk 2005, Kolodiuk et al. 2009, 2010, Ribeiro 2010, Freire et al. 2009). The arboreal and terrestrial habits of L. klugei and M. heathi, respectively, confirmed profiles already described in other Caatinga site (Vitt 1995).

Phyllopezus periosus and P. pollicaris showed a high fidelity to the habitat of ARF and used the microhabitats of Rock Outcrop (RO), Crack of Rock Outcrop (CRO) and or On Boulder (OB), confirming their saxicolous character already stated in other works (Rodrigues 1986, Vitt 1995, Rodrigues 2003, Maggi 2005). However, the relatively common occurrence of both species in microhabitat categories associated to vegetation contradict the results of Maggi (2005), where just $P$. pollicaris made significant use of vegetation associated to the ARF habitat. In this case, the differences between the two studies may be related to methodological differences. Besides the rock outcrops, this study considered checking regularly the surrounding vegetation of the ARF habitat, where several records, mainly of $P$. periosus, were made, suggesting some degree of arboreal habits for this species. This suggestion is supported by in loco observations of trees, more than 5 meters away from the rock outcrops, where individuals were seen roosting more than $2 \mathrm{~m}$ above the ground (Figure 3E).

The low overlapping indexes for microhabitat usage, obtained for most of the species pairs, may be considered a relevant factor for the co-occurrence of the lizard species in the studied assemblage. For pairs of species showing high overlapping in this niche dimension, it is possible to infer probable dimensions where segregation occurs. In the case of the tropidurids, for example, the two species differ in 
the vertical use of the rocky microhabitats, with $T$. hispidus using a larger vertical microhabitat range (Ribeiro 2010); in addition, the diet and foraging behavior of T. hispidus and T. semitaeniatus overlap under limiting conditions during the dry season, but are segregative factors that may contribute to the coexistence of these species in the wet season (Kolodiuk et al. 2010, Ribeiro \& Freire 2011b). In the case of $P$. periosus and $P$. pollicaris, Maggi (2005) suggests that a difference in diet composition, enabled by differences in body size and foraging behavior between the two species, is the probable factor allowing the coexistence of them.

The activity periods of the dominant species reported in this study, where the tropidurids showed a wide activity period, being active all day long, with a reduction of activity during the hottest hours, while $A$. cf. ocellifera presented unimodal activity with a peak during the hottest hours of the day, also confirm data already described for the ESEC Seridó (Kolodiuk 2005, Maggi 2005, Freire et al. 2009, Ribeiro 2010, Ribeiro \& Freire 2010), as well as some others performed in other areas of the Caatinga (Vitt 1995, Falcão 2006).

The activity profile recorded in this study for L. klugei differs in part with the profile described for other populations of this species in the Caatinga (e. g. Vitt 1995), because this species was active all day long in the ESEC Seridó. On the other hand, the bimodal profile exhibited by $M$. heathi in the ESEC, with activity during early morning and late afternoon, corroborates what was described in a study performed in the Cerrado (Sado et al. 2007) and in a study performed in the Atlantic Rainforest (Sales et al. 2009).

The seasonality of the ESEC Seridó affected the activity periods of diurnal lizards, corroborating previous results (Kolodiuk 2005, Kolodiuk et al. 2009, 2010, Ribeiro \& Freire 2010, Ribeiro 2010). The lack of activity of the tropidurids and L. klugei in the hottest hours during the dry season may reflect, for example, the strong relation between environmental temperature and body temperature in these species, as all of them are ambush foragers (Rocha \& Bergallo 1990, Vitt 1995). Preferential use of shaded environments by tropidurids during the dry season corroborated the results of Ribeiro \& Freire (2010). Lygodactylus klugei used mainly shaded environments in both seasons, a trend also described by Vitt (1995). Ameivula cf. ocellifera, on the other hand, used in a preferential way sunny environments during both seasons, thus confirming the condition of an active forager needing to keep elevated body temperatures while active (Vitt 1995, Rocha et al. 2009, Menezes \& Rocha 2011, Menezes et al. 2011).

\section{Conclusion}

The abundance of the species, and the profiles of time and space usage by the dominant species, corroborate long-term studies previously performed in the ESEC Seridó and suggest the existence of patterns in time and space usage in the lizard assemblage of this ESEC. Seasonal effects are remarkable and interfere mostly in the abundance of active individuals in the field and activity periods of the species. The overlapping in niche dimensions recorded for some pairs of species does not limit the co-occurrence of these, as they tend to be segregated in other variables like diet, activity periods, habitat and/or microhabitat.

\section{Acknowledgments}

We thank the Programa PELD/CNPq-Caatinga: Estrutura e Funcionamento (process $n^{\circ} 521134 / 01$ ) for logistic support, and the administration and employees of the Estação Ecológica do Seridó - ESEC/IBAMA for allowing research and for the housing provided during the field work. MJM Andrade and EMX Freire received research grants from $\mathrm{CNPq}$, and IBAMA issued the required permit (Permit 206/2006 and Process 02001.004294/03-15).

\section{References}

ALbUQUerque U.P., ARAÚJO, E.L., EL-DEIR, A.C.A., LIMA, A.L.A., SOUTO, A., BEZERRA, B.M., FERRAZ, E.M.N., FREIRE, E.M.X., SAMPAIO, E.V.S.B., LAS-CASAS, F.M.G., MOURA, G.J.B., PEREIRA, G.A., MELO, J.G., RAMOS, M.A., RODAL, M.J.N., SCHIEL, N., LYRA-NEVES, R.M., ALVES, R.R.N., AZEVEDOJÚNIOR, S.M., TELINO JÚNIOR, W.R. \& SEVERI, W. 2012. Caatinga revisited: ecology and conservation of an important seasonal dry forest. Sci. World J. 2012:1-18. PMid:22919296 PMCid:PMC3415163. http:// dx.doi.org/10.1100/2012/205182

ANDRADE-LIMA, D. 1981. The caatingas dominium. Rev. Bras. Bot. 4(2):149-153.

ARIAS, F., CARVALHO C.M., RODRIGUES, M.T. \& ZAHER, H. 2011a. Two new species of Cnemidophorus (Squamata: Teiidae) from the Caatinga, northwest Brazil. Zootaxa. 2787:37-54.

ARIAS, F., CARVALHO C.M., RODRIGUES, M.T. \& ZAHER, H. $2011 \mathrm{~b}$. Two new species of Cnemidophorus (Squamata: Teiidae) of the $C$. ocellifer group, from Bahia, Brazil. Zootaxa. 3022:1-21.

BORGES-NOJOSA, D.M \& ARZABE, C. 2005. Diversidade de anfíbios e répteis em áreas prioritárias para a conservação da Caatinga. In Análise das variações da biodiversidade do bioma caatinga: suporte a estratégias regionais de conservação (F.S. Araújo, M.J.N. Rodal \& M.R.V. Barbosa, orgs.). MMA, Brasília, p.227-241.

FALCÃO, A.C.G.P. 2006. Uso de hábitat e período de atividade de Tropidurus e Cnemidophorus na Caatinga em São João do Cariri, Paraíba. Monografia de graduação, Universidade Federal da Paraíba, Paraíba.

FREIRE, E.M.X., FEIO, R.N. \& POMBAL JUNIOR, J.P. 2000. Geographic Distribution. Phyllopezus periosus. Herpetol. Rev. 31:54.

FREIRE, E.M.X. 2001. Composição, Taxonomia, Diversidade e considerações Zoogeográficas sobre a Fauna de Lagartos e Serpentes de Remanescentes da Mata Atlântica do Estado de Alagoas, Brasil. Tese de Doutorado, Universidade Federal do Rio de Janeiro, Rio de Janeiro.

FREIRE, E.M.X., SKUK, G.O.S., KOLODIUK, M.F., RIBEIRO, L.B., MAGGI, B.S., RODRIGUES, L.S., VIEIRA, W.L.S. \& FALCÃO, A.C.G.P. 2009. Répteis das Caatingas do seridó do Rio Grande do Norte e do cariri da Paraíba: síntese do conhecimento atual e perspectivas. In Recursos Naturais das Caatingas: Uma Visão Multidisciplinar (E.M.X. Freire, org.). EdUFRN, Natal, p.51-84.

GARDA, A.A., COSTA, T.B., SANTOS-SILVA, C.R., MESQUITA, D.O., FARIA, R.G., CONCEIÇÃO, B.M., SILVA, I.R.S., FERREIRA, A.S., ROCHA, S.M., PALMEIRA, C.N.S., RODRIGUES, R., FERRARI, S.F. \& TORQUATO, S. 2013. Herpetofauna of protected areas in the Caatinga I: Raso da Catarina Ecological Station (Bahia, Brazil). Check List 9(2):405-414.

KENNEY A.J. \& C.J. KREBS. 2000. Programs for Ecological Methodology. 2. ed. University of British Columbia, Vancouver.

KOLODIUK, M.F. 2005. Uso de habitats e período de atividade das espécies de lagartos dominantes da Caatinga da Estação Ecológica do Seridó, Rio Grande do Norte. Monografia de graduação, Universidade Federal do Rio Grande do Norte, Rio Grande do Norte.

KOLODIUK, M.F., RIBEIRO, L.B. \& FREIRE, E.M.X., 2009. The effects of seasonality on the foraging behavior of Tropidurus hispidus and Tropidurus semitaeniatus (Squamata,Tropiduridae) living in sympatry in the Caatinga of northeastern Brazil. Zoologia 26(3):581-585. http:// dx.doi.org/10.1590/S1984-46702009000300026

KOLODIUK, M.F., RIBEIRO, L.B. \& FREIRE, E.M.X. 2010. Diet and foraging behavior of two species of Tropidurus (Squamata, Tropiduridae) in the Caatinga of northeastern Brazil. S. Am. J. Herpetol. 5(1):35-44. http://dx.doi.org/10.2994/057.005.0104

LEAL, I.R., TABARELLI, M. \& SILVA, J.M.C. 2003. Ecologia e conservação da caatinga: uma introdução ao desafio. In Ecologia e Conservação da Caatinga (I.R. Leal, M. Tabarelli \& J.M.C. Silva, eds.). Ed. Universitária da UFPE, Recife, p.13-18.

LEAL, I.R., SILVA, J.M.C., TABARELLI, M. \& LACHER, T.E., JUNIOR. 2005. Mudando o curso da conservação da biodiversidade na Caatinga do Nordeste do Brasil. Megadiversidade 1:139-146.

MAGURRAN, A.E. 1988. Ecological Diversity and its Measurement. Cambridge University Press, London. http://dx.doi.org/10.1007/97894-015-7358-0 
MAGGI, B.S. 2005. Utilização de recursos, ecomorfometria e comportamento em duas espécies sintópicas de geconídeos (Squamata, Gekkonidae) na caatinga. Dissertação de mestrado, Universidade Federal do Rio Grande do Norte, Rio Grande do Norte.

MARES, M.A., WILLIG, M.R., STREILEIN, K.E. \& LACHER, T.E., Jr. 1981. The mammals of northeastern Brazil: a preliminary assessment. Ann. Carnegie Mus. 50:80-137.

MENEZES, V.A. \& ROCHA, C.F.D. 2011. Thermal ecology of five Cnemidophorus species (Squamata: Teiidae) in east coast of Brazil. J. Thermal Biol. 36:157-167. http://dx.doi.org/10.1016/j. jtherbio.2011.03.004

MENEZES, V.A., VAN SLUYS, M., FONTES, A.F. \& ROCHA, C.F.D. 2011. Living in a caatinga-rocky field transitional habitat: ecological aspects of the whiptail lizard Cnemidophorus ocellifer (Teiidae) in northeastern Brazil. Zoologia 28:8-16. http://dx.doi.org/10.1590/S198446702011000100002

MOURA, G.J.B., FREIRE, E.M.X., SANTOS, E.M., MORAIS, Z.M.B., LINS, E.A.M., ANDRADE, E.V.E. \& FERREIRA, J.D.C. 2010 Distribuição geográfica e caracterização ecológica dos répteis do estado de Pernambuco. In Herpetofauna no Estado de Pernambuco (G.J.B. Moura, E.M. Santos, M.A.B. Oliveira \& M.C.C. Cabral, eds.). Ministério do Meio Ambiente, Brasília, DF, p.227-288.

PIANKA, E.R. 1973. The structure of lizard communities. Annu. Rev. Ecol. Syst. 4:53-74. http://dx.doi.org/10.1146/annurev.es.04.110173.000413

RIBEIRO, L.B. 2010. Ecologia comportamental de Tropidurus hispidus e Tropidurus semitaeniatus (Squamata, Tropiduridae) em simpatria, em área de Caatinga do nordeste do Brasil. Tese de doutorado, Universidade Federal do Rio Grande do Norte, Rio Grande do Norte.

RIBEIRO, L.B. \& FREIRE, E.M.X. 2009a. Tropidurus hispidus (NCN). Frog predation. Herpetol. Rev. 40(2):228

RIBEIRO, L.B. \& FREIRE, E.M.X. 2009b. Tropidurus semitaeniatus (NCN). Drinking behavior. Herpetol. Rev. 40(2):228-229.

RIBEIRO, L.B. \& FREIRE, E.M.X. 2010. Thermal ecology and thermoregulatory behavior of Tropidurus hispidus and T. semitaeniatus in a Caatinga area of northeastern Brazil. Herpetol. J. 20:201-208.

RIBEIRO, L.B. \& FREIRE, E.M.X. 2011a. Lagartos como bioindicadores: testando metodologia de avaliação da qualidade ambiental de caatingas e áreas florestadas. In Múltiplos Olhares sobre o Semiárido Brasileiro: Perspectivas Interdisciplinares (E.M.X. Freire, G.A. Cândido \& P.V. Azevedo, orgs). EDUFRN, Natal, p.145-186.

RIBEIRO, L.B. \& FREIRE, E.M.X. 2011b. Trophic ecology and foraging behavior of Tropidurus hispidus and Tropidurus semitaeniatus (Squamata, Tropiduridae) in a caatinga area of northeastern Brazil. Iheringia, Sér. Zool. 101:225-232.

RIBEIRO, L.B., GOGLIATH, M. \& FREIRE, E.M.X. 2008. Tropidurus semitaeniatus (Squamata: Tropiduridae) as a seed disperser of the plant Commiphora leptophloeos (Burseraceae) in the Caatinga of northeastern Brazil. Cuad. Herpetol. 22(2): 91-94.

RIBEIRO, L.B., KOLODIUK, M.F. \& FREIRE, E.M.X. 2010. Ventral colored patches in Tropidurus semitaeniatus (Squamata, Tropiduridae) sexual dimorphism and association with reproductive cycle. J. Herpetol. 44(1):177-182. http://dx.doi.org/10.1670/07-246.1

RIBEIRO, L.B., GOGLIATH, M., SALES, R.F.D. \& FREIRE, E.M.X 2011. Mating behavior and female accompaniment in the whiptail lizard Cnemidophorus ocellifer (Squamata, Teiidae) in the Caatinga region of northeastern Brazil. Biota Neotrop. 11(4):363-368. http://dx.doi. org $/ 10.1590 /$ S1676-06032011000400031

RIBEIRO, L.B., SILVA, N.B. \& FREIRE, E.M.X. 2012. Reproductive and fat body cycles of Tropidurus hispidus and Tropidurus semitaeniatus (Squamata: Tropiduridae) in a caatinga area of northeastern Brazil Ver. Chil. Hist. Nat. 85: 307-320. http://dx.doi.org/10.4067/S0716078X2012000300005

ROCHA, C.F.D.1994. A ecologia de lagartos no Brasil: status e perspectivas. In Herpetologia no Brasil I (L.B. Nascimento, A.T. Bernardes \& G.A. Cotta, eds). PUC/MG, Fundação Biodiversitas e Fundação Ezequiel Dias, Minas Gerais, p.35-57. PMid:8034556
ROCHA, C.F.D. \& BERGALLO, H.G. 1990. Thermal biology and flight distance of Tropidurus oreadicus (Sauria: Iguanidae) in an area of Amazonian Brazil. Ethol. Ecol. Evol. 2:263-268. http://dx.doi.org/10.1 080/08927014.1990.9525411

ROCHA, C.F.D., VAN SLUYS, M., VRCIBRADIC, D., KIEFER, M.C., MENEZES, V.A., SIQUEIRA, C.C. 2009. Comportamento de termorregulação em lagartos brasileiros. Oecol. Bras. 13:115-131.

ROCHA, C.F.D., ANJOS, L.A. \& BERGALLO, H.G. 2011. Conquering Brazil: the invasion by the exotic gekkonid lizard Hemidactylus mabouia (Squamata) in Brazilian natural environments. Zoologia 28(6):747-754. http://dx.doi.org/10.1590/S1984-46702011000600007

RODRIGUES, M. T.1986. Uma nova espécie do gênero Phyllopezus de Cabaceiras: Paraíba: Brasil; com comentários sobre a fauna de lagartos da área (Sauria Gekkonidae). Pap. Avulsos Zool. 36(20):237-250.

RODRIGUES, M.T. 1996. Lizards, snakes and amphisbaenians from the Quaternary sand dunes of the middle Rio São Francisco, Bahia, Brazil. J. Herpetol. 30:513-523. http://dx.doi.org/10.2307/1565694

RODRIGUES, M.T. 2003. Herpetofauna da Caatinga. In Ecologia e Conservação da Caatinga (I.R. Leal, M. Tabarelli \& J.M.C. Silva, eds). Ed. Universitária da UFPE, Recife, p.489-540.

RODRIGUES, M.T. 2005. Conservação dos répteis brasileiros: os desafios para um país megadiverso. Megadiversidade. 1:87-94.

SADO, R.R., CARDOSO, R.M., OLIVEIRA, I., TOMATIELI, T.F. \& COLLI, G.R. 2007. Padrão de atividade e termorregulação em lagartos do cerrado. In Anais do VIII Congresso de Ecologia do Brasil, Caxambu, MG.

SALES, R.F.D., LISBOA, C.M.C.A. \& FREIRE, E.M.X. 2009. Répteis Squamata de remanescentes florestais do campus da Universidade Federal do Rio Grande do Norte, Natal-RN, Brasil. Cuad. Herpetol. 23:77-88. http://dx.doi.org/10.2994/057.007.0204

SALES, R.F.D., RIBEIRO, L.B \& FREIRE, E.M.X. 2011a. Feeding ecology of Ameiva ameiva in a Caatinga area of northeastern Brazil. Herpetol. J. 21:199-207.

SALES, R.F.D., RIBEIRO, L.B., JORGE, J.S. \& FREIRE, E.M.X. 2011 b. Habitat use, daily activity periods and thermal ecology of Ameiva ameiva (Squamata: Teiidae) in a caatinga area of northeastern Brazil. Phyllomedusa 10(2):165-176.

SALES, R.F.D., RIBEIRO, L.B., JORGE, J.S. \& FREIRE, E.M.X. 2012 Feeding habits and predator-prey size relationships in the whiptail lizard Cnemidophorus ocellifer (Teiidae) in the semiarid region of Brazil. S. Am. J. Herpetol. 7(2):149-156.

SILVA, J.M.C., TABARELLI, M., FONSECA, M.T. \& LINS, L.V. (orgs.). 2003. Biodiversidade da caatinga: áreas e ações prioritárias para a conservação. MMA UFPE, Brasília.

SIMPSON, E.H. 1949. Measurement of species diversity. Nature. 163:688. http://dx.doi.org/10.1038/163688a0

VANZOLINI, P.E., RAMOS-COSTA, A.M.M. \& VITT, L.J. 1980. Répteis das Caatingas. Academia Brasileira de Ciências, Rio de Janeiro.

VARELA-FREIRE, A.A. 2002. A Caatinga Hiperxerófila do Seridó: a sua Caracterização e Estratégias para sua Conservação. Academia de Ciências do Estado de São Paulo, São Paulo.

VELlOSO, A.L., SAMPAIO, E.V.S.B. \& PAREYN, F.G.C. 2002 Ecorregiões: Propostas para o Bioma Caatinga. Instituto de Conservação Ambiental The Nature Conservancy do Brasil, Recife.

VITT, L.J. 1986. Reproductive tactics of sympatric gekkonid lizards with comment on the evolutionary and ecological consequences of invariant clutch size. Copeia. 3: 773-786.

VITT, L.J.1995. The ecology of tropical lizards in the Caatinga of northeast Brazil. Occas. Pap. Okla. Mus. Nat. Hist. 1:1-29.

WERNECK, F.P., COLLI, G.R. \& VITT, L.J. 2009. Determinants of assemblage structure in neotropical dry forest lizards. Austral Ecol. 34:97115. http://dx.doi.org/10.1111/j.1442-9993.2008.01915.x 
